\title{
Editorial
}

\section{Homeland Insecurities}

\author{
Susette Min \\ University of California, Davis, CA, USA \\ ssmin@ucdavis.edu
}

Beginning in 2015, an influx of more than a million undocumented migrants and refugees from Syria, Afghanistan, Iraq, Sudan, and other countriesnumbers not seen since World War II - crossed into Europe over land via the Balkans and across the Adriatic, Aegean, and Mediterranean Seas. Currently, there are more than 67 million refugees on the move, forced to migrate due to a number of factors-ongoing wars and violence, climate change, repressive governments, financial crisis, and poverty - and paying whatever they can (over the past 15 years, migrants have paid more than $\$ 18.2$ billion Us) in search of a new life. More than 46,00o individuals have died since 2000, and more than 40 million internally displaced people (IDP) have been detained and interned in camps all over the world, some for committing only the offence of crossing — or trying to cross-a border without papers. ${ }^{1}$

1 Missing Migrants Project, "Latest Global Figures: Migrant Fatalities Worldwide," Missing Migrants: Tracking Deaths Along Migratory Routes https://missingmigrants.iom.int/latest-global -figures; Internal Displacement Monitoring Centre, "Global Report on Internal Displacement," IDMC Global Internal Displacement Database, 2016, http://www.internal-displacement .org/globalreport2016/. See also Organization for Economic Co-operation and Development (OECD), "G20 global displacement and migration trends report 2017," (2017): 5, http://www .oecd.org/els/G2o-OECD-migration.pdf; Adrian Edwards, "Forced displacement worldwide at its highest in decades," UN Refugee Agency (UNHCR), 19June 2017, http://www.unhcr.org/en-us/ news/stories/2017/6/5941561f4/forced-displacement-worldwide-its-highest-decades.html; Nick Robins-Early, "Europe's Refugee Crisis Spawns a Billion-Dollar Industry: Refugees and migrants pay smugglers huge sums of money," The World Post, 3January 2017, http://www.huffingtonpost.com/entry/europe-refugees-smuggling-industry_us_55efi426e4bo93be51bc4oof. 
The United Nations' Article 25 of the Universal Declaration of Human Rights; Article 11 of the International Covenant on Economic, Social, and Cultural Rights; the $195^{1}$ Convention Relating to the Status of Refugees; and Article 5 of the Convention on the Elimination of All Forms of Racial Discrimination guarantee, with varying degrees of emphasis, the fundamental human right to work and be secure at home, to live in peace and with dignity. Invisible and authorized, makeshift and permanent, immigration detention centres and refugee border camps are physical spaces of containment, as well as legal spaces of exception that strip individuals of their basic rights. These camps, centres, settlements, and compounds have become spectacles of biopolitical governmentality and statecraft, giving the appearance of keeping the homeland safe and saving lives by offering a humanitarian alternative to capsizing at sea, or suffocating in a truck or shipping container. The construction and expansion of these camps, conceived as stopgap measures, allow nation-states to create a quasi-fictional space between Europe's internal and external borders, but also to buy time as the State rearticulates the meaning of asylum, and regroups migrants into other kinds of categories. On another level, the camps are becoming "limboscapes," as aptly described by Xavier Ferrer Gallardo and Abel Albet-Mas: a long-term solution that violates the inalienable rights of an individual's access to a livelihood and a future or a return to one's homeland. ${ }^{2}$

How has the art world responded to this crisis? Continuing the long tradition of offering critical perspectives on timely issues - much to the dismay on both sides of the political spectrum-Insecurities: Tracing Displacement and Shelter (1 October 2016-22 January 2017) was the New York Museum of Modern Art's modest attempt to address and engage the refugee crisis, highlighting the various ways artists, architects, and designers have addressed notions of forced migration and displacement. ${ }^{3}$ Part of MoMA's ongoing Citizens and Borders series and a natural segue from their summer installation of Bouchra Khalili's installation piece The Mapping Journey Project (2008-2011), Insecurities was organized by in-house curators Sean Anderson and Arièle Dionne-Krosnick.

Located on the second floor of the museum, at one of the two entrances to the single-room exhibition, was UNITED's List of Deaths: statistical details of

2 Xavier Ferrer-Gallardo and Abel Albet-Mas, "EU-Limboscapes: Ceuta and the Proliferation of Migrant Detention Spaces across the European Union," European Urban and Regional Studies 20, no. 4 (2013): 1-4.

3 In February 2017, MoMA also rehung part of its permanent collection on its fifth-floor galleries interspersed with artworks by artists, such as Ibrahim el-Salahi and Tala Madani, from majority-Muslim nations included in Trump's executive order on immigration. 
more than 22,000 migrants and refugees, many of them unidentified. ${ }^{4}$ Inside the entry to the gallery space hung Xaviera Simmons' grid of forty-two photographs of migrants on boats stranded in the Mediterranean Sea, and Tiffany Chung's lightbox installation of images of the ruined landscape of Homs. While some of the works represented the fateful journey of crossing borders and the effect of being displaced and living precariously - exemplified by Reena Saini Kallat's Woven Chronicle (2011/2016), made of multicoloured wires and intermittent sounds of sirens, horns, and hums - the majority of the works in the exhibition were images of makeshift camps, temporary and semi-permanent shelters, and settlements: architectural designs of natural disaster-resistant shelters; a tapestry of Rabouni (a camp in the Algerian desert) created by the National Union of Sahrawi Women in collaboration with Manuel Herz Architects; and a hand-drawn map by Jan Rothuizen projected onto the floor. The exhibition was also a mixed display of emergency artifacts, supplies, and structures, including Better Shelter's steel-frame tent designed by the I KEA Foundation and UNHCR, and, placed on a pedestal, a colour-coded plastic bracelet used by Doctors Without Borders to measure arm circumference and gauge malnutrition.

In one corner of the gallery, next to Tiffany Chung's colourful maps that trace the regional movements of thousands of refugees from Syria, Jordan, Lebanon, and Turkey, was Dorothea Lange's iconic photograph Migrant Mother, Nipomo, California (1936). Absent, however, was Lange's poignant documentation of another mass exodus and incarceration: the processing of Japanese Americans at various temporary "assembly centers," waiting in line to be tagged, their orderly rows of suitcases ready to be loaded and transported on buses and trains to relocation centres in rural Arkansas, Arizona, California, Idaho, Utah, and Wyoming. On 19 February 1942, Franklin D. Roosevelt's Executive Order (EO) 9066 called for the forced removal and incarceration of 120,000 Japanese Americans from the West Coast, Arizona, and along the Mexican border. Marked and targeted as an internal foreign menace and enemy of the people, Japanese Americans were rounded up en masse and stripped of their rights as us citizens.

Since shortly after $9 / 11$, Japanese Americans have been at the forefront of protests against racial and religious profiling - including the National Security Entry-Exit Registration System (NSEERS) - by highlighting the history of their own mistreatment and the consequences of fearmongering and singling out a

4 United for Intercultural Action, "United List of Deaths Presented at MoMA Exhibition," 7 October 2016, accessed 27 July 2017, http://www.unitedagainstracism.org/blog/2016/10/o7/ united-list-of-deaths-presented-at-moma-exhibition. 
class of people. According to former member of the us House of Representatives Norman Mineta, Japanese Americans need to be vigilant, having "a particular moral obligation to remind people that measures like the Muslim ban are not just unconstitutional, they are un-American (...) [and] undermine the very thing that sets our country apart: our enduring commitment to freedom and justice for all." 5

Over the years, this "moral task" to remember the Internment has been taken on by a number of cultural producers and visual artists who represent the camp experience and its impact on multiple generations of Japanese Americans. Other artists such as Rea Tajiri, Margaret Honda, and Kim Yasuda have focused on the filtering and whitewashing of information about the Internment, part of the growing evidence that points to the grave injustices the Japanese American community continues to endure. Contrary to the aims of us House of Representatives Bill 442-or the Civil Liberties Act of 1987, which included a formal apology, $\$ 20,000$ us in reparations, and a guarantee that future generations of Americans would not have to endure the same fate of shame, humiliation, and guilt - recent political speeches, news interviews, and comments on social media reveal an apparent return to racist and outdated mindsets. Just last year in an interview with Megyn Kelly on Fox news, former Navy SEAL Carl Higbie characterized EO 9066 as a precedent for the proposed national registry of Muslims, justifying the actions of the us government in interning Japanese Americans - understood at the time as "enemy combatants" - and describing Syrian refugees as security risks. The Executive Office of the President's call for the exclusion of all refugees and the deportation of 11 million undocumented immigrants-who President Trump characterizes as "potential terrorists" and "removable aliens" - in the name of security, alongside the increase in millions of dollars in funding for immigration law enforcement and contractual partnerships with entities such as Corrections Corporation of America, Geo Group, and к BR (a subsidiary of Halliburton, formerly known as Kellogg, Brown, and Root) to construct new detention centres all over the us highlights how old strategies to deal with the racialized "other" have returned with a vengeance. ${ }^{6}$

5 Teresa Watanabe, "A Chilling Moment to Mark the 75th Anniversary of the Executive Order that Led to Japanese American Internment," Los Angeles Times, 19 February 2017, http://www .latimes.com/local/education/la-me-japanese-executive-order-20170219-story.html.

6 Mirren Gidda, "Private Prison Company geo Group Gave Generously to Trump and now has Lucrative Contract," Newsweek, 11 May 2017, http://www.newsweek.com/geo-group-private -prisons-immigration-detention-trump-596505; In the Public Interest, "GEO Group and Corrections Corporation of America Spend Billions of Taxpayer Dollars Purchasing Smaller Companies," Programs Not Profit Factsheet, September 2016, https://www.inthepublicinterest .org/wp-content/uploads/ITPI_PrivatePrisonsMnA_FactSheet_Sept2016.pdf; and Seth Freed 
The symbolism of the Japanese American internment camp-which was supposed to be an exceptional artifact—-has mutated into a humanitarian front and intensified mechanism of migration control. Once euphemistically and deceptively called "temporary homes" and "wayside stations" by former Director of the War Relocation Authority (WRA) Dillon S. Myer, such sites have now been renamed as "reception centers" and "transit service points," different configurations of "camps of control," that "provide an important gauge of [current] local and global situations." ${ }^{7}$

February 19th of this year marked the seventy-fifth anniversary of the Japanese American internment and is the occasion for this special issue of Asian Diasporic Visual Cultures and the Americas. Mindful of the differing conditions and circumstances of the Japanese American internment, the current global migrant and refugee crisis, and anti-immigrant sentiments in Europe, the Middle East, and the us, the essays and reviews address in different ways the camp as a structure, a site, and an event. In the introduction, I hope to make some links that open up new analytical frameworks through which to consider the camp as a site of disruption and decolonizing consciousness, rather than simply displacement and death.

At the time of EO 9066, engineers and architects from the Farm Security Administration were called upon by the us government to hastily construct or convert horse stables and former military barracks into assembly centres, war relocation/incarceration centres, and Department of Justice camps. In 1942, Poston, in Arizona, was one of the largest relocation centres, filled to capacity with 17,814 internees. As co-founder and part of Nisei Writers and Artists Mobilization for Democracy and in solidarity with his fellow Japanese Americans, artist Isamu Noguchi volunteered to enter Poston on 12 May 1942. Despite being subjected to the same poor treatment as his Japanese American peers - forced to stand in long lines to enter the canteen - Noguchi was seen with suspicion by his fellow internees because of his special status through which he was given his own room in the barracks. Frustrated that his demands

Wessler, "ICE Plans to Reopen the Very Same Private Prison the Feds Just Closed," The Nation, 27 October 2016, https://www.thenation.com/article/ice-plans-to-reopen-the-very -same-private-prison-the-feds-just-closed/.

7 Charles Hailey, Camps: A Guide to 21st-Century Space (Cambridge, MA: MIT Press, 2009), 1. See also Giorgio Agamben, Means Without End (Minneapolis: University of Minnesota Press, 2000), 37-45. 
for materials to set up an arts-and-crafts program and improve the living conditions of the camps went unheeded by the WRA despite long conversations with the Commissioner of the Bureau of Indian Affairs, Noguchi requested a furlough. Seven months after his entry into the camps, he was discharged.

The exhibition Self-Interned, 1942: Noguchi in Poston War Relocation Center (2016) opened at the Noguchi Museum in Long Island, New York around the same time as Insecurities, and focused primarily on the impact of Noguchi's experience at Poston on his art making. Enamoured with the desert landscape, where he discovered ironwood roots to be a perfect material for sculpting, Noguchi produced a number of works soon after his release, including Monument to Heroes (1943), My Arizona (1943), and This Tortured Earth (1943). I am interested in his vision and "moral authority" to redesign the camps-a motivational desire akin to the objectives of a number of designers and architects showcased in Insecurities. Approaching Poston as an opportunity, Noguchi envisioned a model community with schools, a cemetery, various recreational facilities-including a swimming pool, zoo, and miniature golf course-and a botanical garden with amoeboid paths and level changes that he would later implement in his design of the Unesco Garden of Peace in Paris. Upon Noguchi's arrival in 1942, the camps were barely inhabitable, as candidly illustrated by Miné Okubo in Citizen 13600 (1946), and attested to in a number of letters, testimonies, interviews, and literary texts on the Internment experience. Engaged in shikata ga nai-"making the best of out their situation"-Japanese Americans constructed furniture out of scrap lumber and found wood, and created their own bonsai and vegetable flower gardens. Fulfilling other parts of Noguchi's vision for the camps, artists such as Chiura Obata set up schools and arts and crafts workshops in an attempt to live a meaningful life in captivity, as documented and depicted in Obata's Silent Moonlight at Tanforan Relocation Center (1942), Henry Sugimoto's Longing (1944), Tokio Ueyama's The Evacuee (1942), and many other artworks exhibited in A View from Within: JapaneseAmerican Art from the Internment Camps 1942-1945 (1992) curated by Karin Higa. ${ }^{8}$ A number of these paintings were made and presented in contemporaneous travelling exhibitions in an attempt to humanize the Japanese; in the same vein as Ansel Adams' book Born Free and Equal (1944), they sought to foreground their dignity and Americanness.

Paintings by George Matsusaburo Hibi (director of the art school at Topaz War Relocation Center) of the desert landscape and the sweeping view of row after row of barracks against a grey and bleak snowscape came to mind when

8 Kristen Hare, "Obata Reflects," Kemper Art Museum, repost from The St. Louis Beacon, 18 September 2009, http://kemperartmuseum.wustl.edu/news/2506. 
I saw Tobias Hutzler's photographs of refugee container camps (Nizip II, 2014) in both Insecurities and in a recent New York Times Magazine feature, "How to Build a Perfect Refugee Camp." ${ }^{\prime 2}$ The article, by Mac McClelland with documentation by Hutzler, centres on Kilis camp, located on the Turkish-Syrian border, north of Aleppo. The camp is surrounded by rows of high fencing, winding coils of barbed wire, and armed police and private security, but the full-colour photographs imply the contrary. Even the picture of the entryway, taken from a distance, seems surprisingly open, accentuated by high midday sunlight, showing people walking freely away from the entrance of the camps. The photographic spread presents orderly rows of storage containers with adults and children hanging out outside, or watching television, or milling about on paved brick walkways that surround the camp. The article describes the camp's "perfection" in terms of its cleanliness, full access to electricity, and a number of schools, playgrounds, and healthcare facilities. While the camp may realize some of Noguchi's physical conditions for a model camp community, it is only towards the conclusion that the author mentions the inability of these migrants to find work, the limits of their autonomy, and the extralegal permanence of their situation. Less about perfecting the refugee camp than perfecting the externalization of the processing and housing of migrants, the article is implicitly about Kilis as a successful outcome of bilateral agreements between the EU and Turkey. Increasingly, in exchange for tighter monitoring of the "external" border of the Eu, billions of dollars are given by individual European countries and NGOs to these outer host countries with promises to not only maintain these camps, but to fund jobs and also improve the country's larger infrastructure. But in doing so, it assigns the problems of migration and citizenship onto these host countries, which have quickly and flatly rejected the transference of such a responsibility. With no opportunities for livelihood and no recourse to citizenship, the residents of such camps remain in a default solution, an open prison.

In the 1940s, the Japanese Americans were stateless fugitives, uprooted from their lives and entrapped in camps where they were unsure of their fate, racially dispossessed of their citizenship, property, and future. Extending their earlier

9 Mac McClelland, "How to Build a Perfect Refugee Camp," The New York Times Magazine, 13 February 2014, https://www.nytimes.com/2014/02/16/magazine/how-to-build-a-perfect -refugee-camp.html. The Sahrawi camp in Algeria, highlighted by the woven rug in Insecurities, could also serve as the model refugee camp. Known for its stable environment, such semi-sovereign autonomy comes with a price. Since 1975, Morocco has occupied part of the Sahrawi's former homeland in the Western Sahara and they have little pressure to withdraw; at the same time the Sahrawi are getting increasing pressure from the refugees to make their plight visible in order to continue receiving funding for their limited existence. 
research on the ethics and paradoxes of designing the barracks and prison cities of the Internment, Lynne Horiuchi and Anoma Pieris focus their attention on Manzanar, which first operated as a reception centre, then as one of ten incarceration centres between 1942 and 1945. In 1992 it was declared a national historical site. In their article "Temporal Cities: Commemoration at Manzanar, California and Cowra, Australia," Horiuchi and Pieris compare the remaking of Manzanar as a commemorative site with the complete renovation of Camp No. 12 at Cowra-one of a number of pow and internment camps in New South Wales, Australia — and the transpacific interconnections of wartime architectural construction, incarceration histories, and heritage strategies imposed on both sites by us and Australian governmental historic preservation officers. Part cautionary tale, the article highlights how Camp No. 12 has been mobilized as a diplomatic tool for reconciliation with former enemy nations such as Japan, and as a symbol of Australia's racial tolerance and cultural pluralism; rather than a place of remembrance of the trauma and injustice that took place there in the 1940s. Troubling too is how the history of Australia's White policy (1901-1973) and its legacy as a penal colony-in combination with current hardline immigration policies—-have also been subordinated and covered over.

In correspondence with the makeover at Cowra, Horiuchi and Pieris highlight the garden management plans at Manzanar to recreate and integrate Japanese-style bonsai and floral gardens cultivated during the Internment, a move that risks transforming the current site's yearly memorial pilgrimage into a picturesque tour. Responding to the authors' ambivalence toward the project, I want to briefly suggest another way to approach the restoration of the gardens at Manzanar, drawing from Ikyo Day's recent book Alien Capital: Asian Racialization and the Logic of Settler Colonial Capitalism (Durham: Duke University Press, 2016) and juxtaposing it with Masumi Hayashi's photographs of the war relocation centers. Located in the high desert of Owens Valley, northeast of Los Angeles near the Sierra Nevada mountains, Manzanar was known, then and now, for its harsh and extreme climate. Part of colonized Native American land, before the arrival of the interned Japanese Americans, Manzanar was a region where the mixture of volcanic soil and the construction of the Owens River-Los Angeles aqueduct created a fertile foundation for apple and fruit orchards until the early 1930s, when the city of Los Angeles shut off irrigation completely.

In contrast to the 1890 s, when inconsistent interpretations of general immigration policy by inspectors led to the exclusion of Japanese American labourers because they were seen as unable to financially support themselves, in the 1940 s the same racist reasoning could not be applied. Vital to California's 
growing agricultural industry and racialized economy, the prosperity and growing acreage owned by Japanese Americans were also seen as economic threats or, as characterized by Day, an offensive form of capital that needed to be contained or obliterated. Responding to Colleen Lye's call for a broader consideration of the Internment, Day offers a more granular historical context for the incarceration of Japanese Americans at this time-usually understood as part of a long legacy of anti-Asian racism - that reveals an intriguing take on capitalism's irrationality, or a diagnosis of how the success of capitalism can lead to ideals of romantic anti-capitalism.

Accused of espionage but also of possessing an "inorganic power" that led to the abstracted personification of evil, Japanese Americans were interned and at the same time forced to give the appearance that they were contributing to the Us war effort and the economy. ${ }^{10}$ In addition to digging irrigation canals and tending acres of fruits and vegetables for low wages, they used their skills and fortitude to construct and cultivate vegetable, floral, and miniature bonsai gardens and ponds, the latter made of found rocks, wood, and other materials throughout the camps. The transformation of the land upon which the Japanese Americans resided, and the emergence of these serene gardens on arid land on one level indexes the production of a social space, and on another level, represents precisely the perceived dangerous efficiency and industriousness for which they were interned. Framed within the context of internment as unfree subjugated day labourers, however, their "dirt-under-the-fingernails" relationship to the land produced a counter-reaction and non-material benefit; an aesthetic dimension to their utilitarian bodies, analogous to the travelling works of art made by prisoners in the camps that highlighted the human worth of the Japanese.

With the awareness that refurbishing these gardens might aestheticize rather than recollect and make palpable the rawness of deracination and everyday life in the camps, the inclusion of Hayashi's photographs of the Internment on and of the Manzanar site offers the potential of a disruptive encounter of this recognizable historical landscape, or at the very least an alternative visitor experience, counter to most heritage and landmark sites that aim to forge a sense of empathy or authenticity. Jason Francisco's "A Tower to Console the Dead and the Living: Masumi Hayashi and the Image of History" introduces us to

10 Taking a departure from Lisa Lowe's focus in Immigrant Acts: On Asian American Cultural Politics (Durham: Duke University Press, 1996) on the contradictions of abstract labour and how capitalism profits from racialized and gendered divisions of labour, Day's book focuses on a wide range of topics including how U.S. capitalism profited from the social productions of racialized difference, abstract labour's dialectical relation to concrete labour, and how Asians have given shape to the abstract circuits of capitalism. 
this remarkable yet under-recognized artist. In contrast to the documentary photographs of the camps on the National Park website for Manzanar, or the photographs by Ansel Adams that recorded the internment camps and its surroundings from the vantage point of a guard tower-evidence of its existence-Hayashi depicts its remains.

Through long exposure, Hayashi's photo collages render a 36o-degree panoramic view of the camp and surrounding landscape. Meticulous in her calculation and composition of each image tile that makes up her "chronopanoramic" collages - spending long periods of time leaving the shutter open to capture the expansive landscape-Hayashi draws the viewer in through the formality of a folded grid; at the same time, the collage structure opens up the image, akin to a Deleuzian fold, undermining, as Francisco describes, a "single experience of seeing."

In his essay, Francisco's larger aim is to position Hayashi's representational and spatial practice as a radical break from the traditional documentary photography and image-making of the Japanese American internment. This endeavour evokes Martha Rosler's call for a radical documentary practice in her landmark essay "In, Around, and Afterthoughts (On Documentary Photography)" (1981) in which she critically tracked how the genre shifted from recording an experience or event, motivated by a moral imperative to reform, to a voyeuristic and aesthetic impulse in capturing an experience or moment, bound up with institutional and artistic authority. ${ }^{11}$ Aware of how images are interpreted and consumed by a combination of information, desires, cultural mythologies, and encoded values, Hayashi refuses to supply the viewer with a moral standpoint. At the same time, her careful set-up of the camera allows what photography does best: to reveal the world to us, and specifically in this case, our notion of and mortal relationship to the land.

The degradation of the land has been largely an artificially manufactured catastrophe caused by a number of factors: the legacy of colonialism, white supremacy, and the rapacity of racialized and fossil fuel-based capitalism. Because increasing parts of the earth have become uninhabitable in particular regions around the world, geopolitical strategies have shifted from one of expansion and development to one of de-development and de-possession. While Japanese Americans were unsure of their fate and the length of their internment at the time, their resettlement, undertaken by the WRA, was slowly but already underway, as we know now from historical records. The timeline for Palestinians, refugees, and migrants in the camps drags on with no end in sight

11 Martha Rosler, "In, Around, and Afterthoughts (On Documentary Photography)," in The Context of Meaning: Critical Histories of Photography, edited by Richard Bolton (Massachusetts: MIT Press, 1981), 303-325. 
where; much of their time is spent waiting. ${ }^{12}$ In contrast to the exploitation of the Japanese Americans during World War II, there is little to no contingency plan to integrate these refugees and migrants into the larger economy or create or structural investment within the migrant camps in Europe and the Palestinian refugee camps and settlements. The denigration of a productive life within these places through de-development-which Sara Roy defines as "a process which undermines or weakens the ability of an economy to grow and expand"13 - has led to the dissolution of global social relations and loss of local autonomy, but also marks the end of any romantic anti-capitalist thoughts or longings. Capitalism's inexorable demands and the literal loss of ground in our desperate clinging to an unsustainable petrocracy has led what I fear is a planned obsolescence of these camps and settlements, an endgame of securitization that radically shifts the stakes and objectives of the displacement foregrounded in the Insecurities exhibition.

In order to thwart these looming catastrophes, Mirzoeff draws from James and Grace Lee Boggs's visionary organizing and inspirational rhetoric on revolution and evolution, emphasizing the need in his article, "Decolonial $\{\mathrm{R}\}$ evolution: Petrocracy and Geological Modernity from Detroit to Palestine and Back," to go beyond capitalist categories and well worn approaches. Challenging the seizure of land that justifies the subjugation of Palestinians to be placed into camps such as Ein as-Sultan, Mirzoeff introduces and applies an "anarcheological" analytic to unsettle for example Israeli's land claims of Telles-Sultan, an archaeological site in the West Bank.

Both his methodology and call to "decolonial revolution" in conjunction with the different topics raised in this special issue bring to mind the work of Sandi Hillal and Alessandra Petri and their hosting, for example, of Pelin Tan and her discussion of "Decolonizing Pedagogies: Towards a Transversal Methodology" that took place at the Dheisheh Refugee Camp, as part of Hillal and Petri's Campus in Camps. ${ }^{14}$ Resisting the architectural tendency to improve refugees' living situations without local and and site-specific input or approaching the individuals in the camps as isolated and passive with no

12 Isamu Noguchi in a letter to Man Ray described this space of waiting in the camps as an "unreal situation" where "time has stop[p]ed and nothing is of consequence, nothing of any value, neither our time and skill." Kathleen Massara, "The Japanese-American Artist Who Went to the Camps to Help," The New Yorker, 31 January 2017. http://www.newyorker.com/ culture/culture-desk/the-japanese-american-artist-who-went-to-the-camps-to-help.

13 Sara Roy, "The Gaza Strip: A Cast of Economic De-Development," Journal of Palestine Studies 17 , no. 1 (1987): 56 .

14 Pelin Tan, "Decolonizing Pedagogies: Towards a Transversal Methodology," Discussion at Edward Said Library, Al Feneiq Center (Dheisheh Refugee Camp) 17 March 2015; http:// www.campusincamps.ps/projects/decolonizing-pedagogies/. 
agency, Hillal and Petri have consistently tried to shift the discourse of camps and refugees by situating it as one of transformation and social intervention. They have for example advocated the Dheisheh refugee camp be designated as a heritage site, and built the concrete plaza at Al Fawwar in the form of a makeshift house without a roof as a means to highlight the lack of public space and private property in refugee camps. Together, their architectural practice and Mirzoeff's essay serve as exciting points of departure and inspiration to begin thinking radically and dialectically about the Japanese American internment camps - for example between Manzanar and Kilis, Poston and Dheisheh. By following the examples set by Hillal, Petri, and Mirzoeff, how might we begin mobilizing and disseminating the rich discourse and artistic archive of the Japanese American internment beyond commemoration and liberal notions of citzenship and applying it, for example, to more profoundly understand the underlying conditions of the Internment camps and the mutation of these sites into humanitarian silos and shadow prisons?

To conclude, I want to return to Hayashi's chronopanoramic photographs as a possible way to begin perceiving the Internment more broadly. In The Miracle of Analogy: Or, The History of Photography, Part 1 (2015), Kaja Silverman suggests approaching the photographic image as an analogy rather than as an index, a strategy that neutralizes our tendency to see things and events, oppressions and traumas hierarchically. ${ }^{15}$ Looking at Hayashi's images of the camps, one tile at a time and then from a distance, summons a constellation of other images, including recognizable ones we associate with the Internment and other similar camps of control. Cumulatively, these images transform into a "screen upon which wider social forces become visible,"16 raising questions on one level of whether a landscape can remember, preserve, and disclose hidden or obscure inscriptions and traces of past ecosystems, ecocides and repressed traumas. By taking the time to look at the erosion of that which remains, the photographs on another level, come to serve as a reminder of the precarious position of certain groups of people and the land, and how we are all bound to the world and subject to an onset of forces and factors that will continue to unsettle us. We can either respond to and act on them, or stay insecure and passive about a global situation that is seemingly becoming more untenable and at risk.

15 Kaja Silverman, The Miracle of Analogy: or The History of Photography, Part 1 (Stanford: Stanford University Press, 2015), 12.

16 Nicholas Mirzoeff, "The Shadow and the Substance: Race, Photography, and the Index," Only Skin Deep: Changing Visions of the American Self, edited by Coco Fusco and Brian Wallis (New York: International Center of Photography/Harry N. Abrams, 2003), 111. 


\section{Susette Min}

is Associate Professor of Asian American Studies and a faculty member of Art History and Cultural Studies at the University of California, Davis. She is also an independent curator, currently working on an exhibition on borders in relation to themes of hostility and hospitality that will open at the Jan Shrem and Maria Manetti Shrem Museum of Art in 2018. She is the author of the forthcoming Unnamable: The Ends of Asian American Art (NYU Press, 2018).

\section{ShiPu Wang (Co-Guest Editor)}

is Associate Professor of Art History and Visual Culture, Founding Faculty of the Global Arts Studies Program, and Founding Director of the Uсм Art Gallery at the University of California, Merced. He is the author of Becoming American? The Art and Identity Crisis of Yasuo Kuniyoshi (University of Hawai'i Press, 2011), The Other American Moderns: Matsura, Ishigaki, Noda, Hayakawa (Penn State University Press, 2017), and Chiura Obata: An American Modern (University of California Press, 2018).

\section{References}

Agamben, Giorgio. Means Without End. Minneapolis: University of Minnesota Press, 2000.

Drinnon, Richard. Keeper of Concentration Camps: Dillon S. Myer and American Racism. Berkeley: University of California Press, 1987.

Ferrer-Gallardo, Xavier, and Albet-Mas, Abel. "EU-Limboscapes: Ceuta and the Proliferation of Migrant Detention Spaces across the European Union." European Urban and Regional Studies 20, no. 4 (2013): 1-4.

Hailey, Charles. Camps: A Guide to 21st-Century Space. Cambridge, MA: MIT Press, 2009. Mirzoeff, Nicholas. "The Shadow and the Substance: Race, Photography, and the Index." In Only Skin Deep: Changing Visions of the American Self. Edited by Coco Fusco and Brian Wallis. New York: International Center of Photography/Harry N. Abrams, 2003. 111-127.

Rosler, Martha. "In, Around, and Afterthoughts (On Documentary Photography)." In The Context of Meaning: Critical Histories of Photography. Edited by Richard Bolton. Cambridge, MA: MIT Press, 1981. 303-325.

Roy, Sara. "The Gaza Strip: A Cast of Economic De-Development." Journal of Palestine Studies 17, no. 1 (1987): 56-88.

Silverman, Kaja. The Miracle of Analogy: Or, The History of Photography, Part ı. Stanford: Stanford University Press, 2015. 